\title{
HUDCO: RATIO ANALYSIS AS A REFLECTION OF FINANCIAL PERFORMANCE
}

\author{
Dr. Navneet Joshi \\ Professor, Jagan Institute of Management Studies, Near Rithal Metro Station, Rohini-sector-5, New \\ Delhi \\ Sanjive Saxena \\ Associate Professor, Jagan Institute of Management Studies, Near Rithal Metro Station, Rohini- \\ sector-5, New Delhi \\ Sakshi, Kathuria \\ PGDM Student, Jagan Institute of Management Studies, Near Rithal Metro Station, Rohini-sector-5, \\ New Delhi
}

Article DOI: https://doi.org/10.36713/epra4594

\begin{abstract}
The current business environment has forced business units to devise innovative means and mechanisms so as to stay competitive in the market. This necessitates the need for constantly evaluating their performance measures. Business units have identified several measures which depict the performance yet ambiguities remain with respect to what is appropriate measure for performance measurement. Ratio analysis is one such measure which business units have been using for sufficient period of time. Yet there exists certain points of consideration which form the basis for this paper and their convergence into research question namely (a) What constitutes ratio analysis and (b) Which of the component of ratio analysis, has the greatest contribution? While addressing these questions, HUDCO's secondary data is used as a base. Ratio analysis is used to depict the measure of performance while descriptive statistics is used for data interpretation. Findings indicate that there is no single component which dominates the contribution and that ratio analysis itself has several components for measurement parameters.
\end{abstract}

KEY WORDS: Components, Descriptive Statistics, Measurements, Ratio Analysis

\section{INTRODUCTION}

HUDCO was established in the year 1970, with the purpose of increasing the speed of housing and urban development of the country. With the passage of time, HUDCO has developed into a premier institution by offering techno financial services including consultancy for housing needs of the country.
However, with the passage of time and with the entry of other competitors in the market, the financial analysis of HUDCO needs to be reviewed. This is primarily due to the fact that in order to remain competitive in the market and in order to sustain at the global level, the business units are required to be take stock of the assets which may necessarily includes the 


\section{EPRA International Journal of Research and Development (IJRD) \\ Volume: 5 | Issue: 6 | June 2020 \\ - Peer Reviewed Journal}

stock of financial health. Ratio analysis is one such tool which depicts an indication of financial health of the business unit.

In simple terms, ratio analysis provides an over view of the financial position of company to many of the stakeholders including investors, financers, bankers, government bodies and the like. The importance of ratio analysis lies in the fact that over a period of time, analysts have struggled with the process of analyzing the business health in terms of financial transactions. However, ratio analysis as a measure is relatively new technique which has stood the test of time.

\section{RESEARCH METHODOLOGY}

The research methodology for this paper followed a structured approach. It commenced with the process of identifying the topic of the study. After several discussions and deliberations, the topic was finally agreed on account of interest.

Once the topic was finalized, the literature review was conducted. The review of the literature was carried by means of several research articles, newspaper clippings pertaining to HUDCO's financial performance and other journals associated with the research process.

An extensive review of the literature, provided the research gap and which led to the formulation of research question. Upon the formulation of the research question, the data collection methodology was deployed. The methodology took into consideration the data concerned with the research question. Descriptive statistics was deployed for the purpose of data collection.

\section{LITERATURE REVIEW}

Several researchers in their study have studied ratio analysis from different perspective. According to Penman \& Nissim (2001) during their study for the analysis of ratio analysis and equity valuation for the period comprising of 1996 to 1999 concluded that the ratio analysis depicted certain trends and patterns when they are deployed for the purpose of forecasting. On the other hand, Carl B, Collier (2004) in their study concluded that financial ratio analysis is complicated and is dependent on the type of the industries in which the business unit is operating. They based their conclusion while studying the financial analysis for Motorola corporation. On the other hand, Vijay S \& Mehta, B (2012) concluded in their study that ratio analysis and the financial performance of the company is impacted by the various subsidies provided by the government from time to time and that this is likely to impact the overall financial health of the company.

Table 1 below depicts the summarized findings of the literature review based on the secondary data from various sources.

\begin{tabular}{|c|c|c|}
\hline Researchers & Research Objective & Findings \\
\hline $\begin{array}{l}\text { Doron Nissim, Stephen } \mathrm{H} . \\
\text { Penman (2001) }\end{array}$ & $\begin{array}{l}\text { To study the practical implication } \\
\text { of Ratio Analysis and Equity } \\
\text { Valuation for the period (1996- } \\
\text { 1999) }\end{array}$ & $\begin{array}{l}\text { It forecasted the time series } \\
\text { behavior of many ratios and } \\
\text { their typical "long-run, steady- } \\
\text { state" levels were } \\
\text { documented. }\end{array}$ \\
\hline $\begin{array}{l}\text { Henry W. Collier, Timothy } \\
\text { Grai,Steve Haslitt and Carl } \\
\text { B. }\end{array}$ & $\begin{array}{l}\text { To construct a financial and } \\
\text { industry analysis for Motorola } \\
\text { corporation }\end{array}$ & $\begin{array}{l}\text { It demonstrates that that } \\
\text { financial ratio analysis is } \\
\text { complicated for companies } \\
\text { that it does not so easily fall } \\
\text { into a single industry. }\end{array}$ \\
\hline $\begin{array}{l}\text { Prof. Vijay S Patel, Prof } \\
\text { Chandresh B Mehta }\end{array}$ & $\begin{array}{l}\text { This paper attempts to study the } \\
\text { profitability ratio of Krishak } \\
\text { Bharati Co-operative Ltd. For } \\
2000-2009\end{array}$ & $\begin{array}{l}\text { Its study reveals that the } \\
\text { income of the company is } \\
\text { based on the subsidy provided } \\
\text { by the government, therefore } \\
\text { the Company should try to } \\
\text { minimize the operating } \\
\text { expenses so as to maintain } \\
\text { profit and it should not back } \\
\text { too much on the subsidy. }\end{array}$ \\
\hline Haile Melkamu Biru & $\begin{array}{l}\text { To analyze the financial } \\
\text { performance of }\end{array}$ & $\begin{array}{l}\text { Dashen bank of Ethiopia } \\
\text { results reflected that it was }\end{array}$ \\
\hline
\end{tabular}




\section{EPRA International Journal of Research and Development (IJRD)}

Volume: 5 | Issue: 6 | June 2020

\begin{tabular}{|c|c|c|}
\hline & Ethiopia & $\begin{array}{l}\text { becoming a prominent and } \\
\text { financially strong bank and } \\
\text { had been attractive to } \\
\text { investors to invest in, but still, } \\
\text { it reflected the need for } \\
\text { improvement in loan default } \\
\text { and efficiency to generate } \\
\text { revenue from earning assets. }\end{array}$ \\
\hline $\begin{array}{l}\text { Omar Durrah, Abdul Aziz } \\
\text { Abdul Rahman, Syed } \\
\text { Ahsan Jamil, Nour Aldeen } \\
\text { Ghafeer }\end{array}$ & $\begin{array}{l}\text { To examine the relationship } \\
\text { between liquidity ratios and } \\
\text { indicators of financial performance } \\
\text { (profitability ratios) in the food } \\
\text { industrial companies listed in } \\
\text { Amman Bursa during the period } \\
(2012-2014)\end{array}$ & $\begin{array}{l}\text { The study pointed the } \\
\text { existence of a positive } \\
\text { relationship between (quick } \\
\text { ratios, defensive interval } \\
\text { ratio) and operating cash flow } \\
\text { margin. There is a positive } \\
\text { relationship between liquidity } \\
\text { ratios (current ratio, quick } \\
\text { ratio, cash ratio) and return } \\
\text { on assets }\end{array}$ \\
\hline $\begin{array}{l}\text { Sugandha Sharmaand Dr. } \\
\text { Navneet Joshi }\end{array}$ & $\begin{array}{l}\text { To investigate the financial health } \\
\text { of ITC over } 10 \text { years. The research } \\
\text { paper aims at measuring the } \\
\text { financial soundness of ITC using } \\
\text { Ratio analysis.(2006-2015) }\end{array}$ & $\begin{array}{l}\text { The study pointed how ratios } \\
\text { help in understanding the } \\
\text { sustained value creation, high } \\
\text { operating profits and high in } \\
\text { terms of cash profits }\end{array}$ \\
\hline $\begin{array}{llll}\text { Shreeda Shah Dr. Viral } \\
\text { Shah }\end{array}$ & $\begin{array}{l}\text { To identify the variability in } \\
\text { profitability, liquidity, Solvency } \\
\text { position in the Visa Steel } \\
\text { Limited.(2012-2013) }\end{array}$ & $\begin{array}{l}\text { The Directors of the company } \\
\text { should pay more attention to } \\
\text { recover the financial position } \\
\text { of the company. }\end{array}$ \\
\hline
\end{tabular}

\section{THE RESEARCH QUESTION}

A review of the extant literature resulted in the formulation of the following research question.

a. What constitutes ratio analysis

b. Which of the component of ratio analysis, has the greatest contribution

\section{RESEARCH OBJECTIVE:}

The research objective pertains to seeking the answers to the research question. The domain addressed through the research objective is the study of the financial rations of HUDCO.

\section{Data Collection}

The collection of the data for this paper was well structured. The structuring was done on the basis of the findings arising out of the literature review. A brain storming session was conducted amongst the authors and later it was decided to include the data collection process for the past 5 years of HUDCO. The reason attributed to the freezing of the data 5 years included the determination of trends and patterns which were conducive to the research objective.

\section{Data analysis}

The data collective from the secondary sources was subjected to statistical analysis. While conducting statistical analysis, descriptive analysis was deployed. The reason for deploying descriptive analysis was the fact that the research was based on the secondary data collected over 5 years, can descriptive analysis, in principle is used to determine and understand the as is situation. In other words, it is conducive to the research objective.

\section{DATA ANALYSIS \& FINDINGS}

\section{a. Earnings per share}

EPS (Earning per share) is a financial ratio which indicates the net profit availability for the various equity shareholders. It is also known as profitability ratio and is used indicates the per share earning capacity of a firm.

The graph below depicts the EPS of HUDCO for the year 2015-19. An analysis of the graph reveals 


\section{EPRA International Journal of Research and Development (IJRD) \\ Volume: 5 | Issue: 6 | June 2020 \\ - Peer Reviewed Journal}

that EPS is increasing at the constant rate and that the

what types of share have gone into the analysis.

financial performance in terms of the earning per share

is promising. However, the graph fails to predict as to

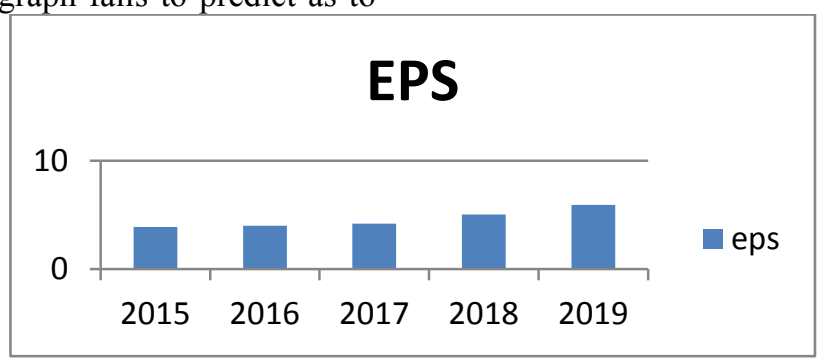

\section{b. Debt Equity Ratio (times)}

Debt Equity ratio reflects the ability of equity pertaining to shareholder to the cover the outstanding in case the business ir required to shutdown the business operations.

From the analysis of the graph it depicts that the business is capable to meet the requirements in case the business is required to be shutdown.

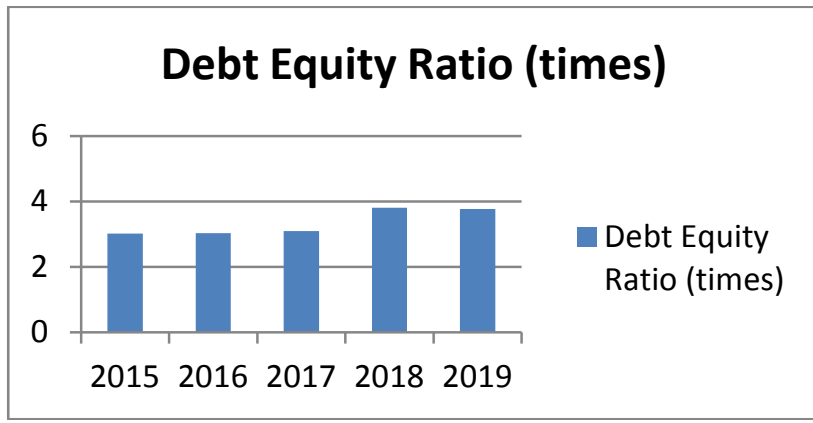

\section{c. Capital Adequacy ratio}

The capital adequacy ratio (CAR) depicts the measurement of a bank's available capital expressed as a percentage of a bank's risk-weighted credit
From the analysis it is evident that the capital adequacy ratio demonstrates a mixed trends and is fluctuating over the period under study.



\section{d. Interest coverage ratio}

The interest coverage ratio is used to depict the easiness of a company who can pay interest expenses for an outstanding debt.
The analysis of the graph depicts that it is fluctuating over the period and that company position is unstable for the amount of the interest to be paid. 


\section{EPRA International Journal of Research and Development (IJRD)

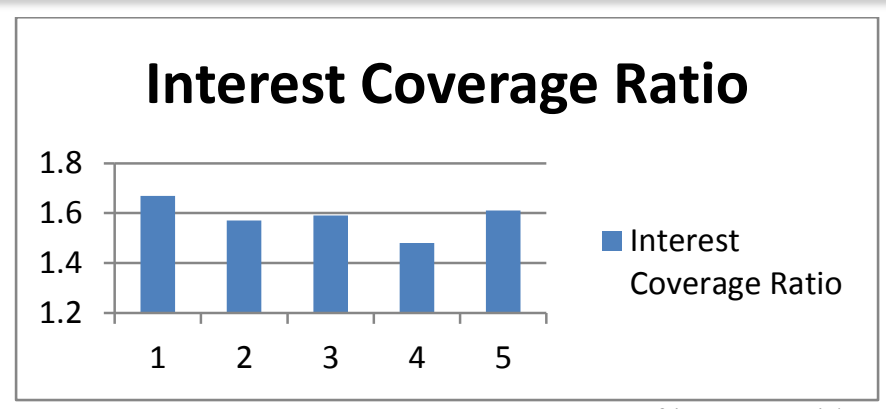

\section{e. Net interest margin}

Net interest margin (NIM) depicts the measure of the difference between an interest income which is generated by banks and other institutions and of the amount of interest paid to lenders as compared to interest-earning assets.

The analysis of the graph depicts that net interest margin is not uniform

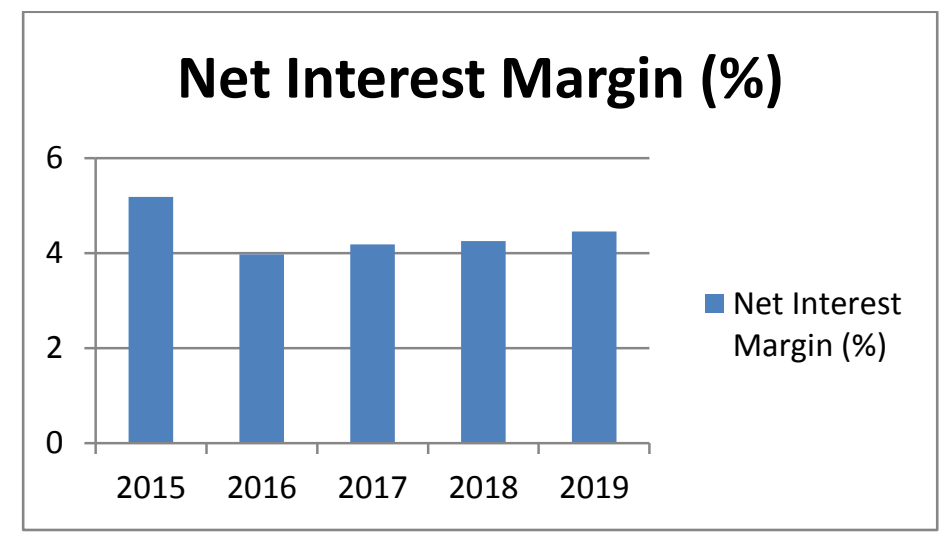

\section{CONCLUSION}

The conclusion is answers the research question and reflects that the ratio analysis comprises of several components and that there is no single component which dominates the contribution

\section{REFERENCES}

1. Tugas, F. C. (2012). A Comparative Analysis of the Financial Ratios of Listed Firms Belonging to the Education Subsector in the Philippines for the Years 2009 -

2. 2011. International Journal of Business and Social Science,3(21).

3. Collier, H. W., Grai, T., Haslitt, S., \& McGowan, C. $B$. (2004). An example of the use of financial ratio analysis: the case of Motorola.

4. Nissim, D., \& Penman, S. H. (2001). Ratio analysis and equity valuation: From research to practice. Review of accounting studies, 6(1), 109-154.

5. Patel V, Mehta C (2012). A Financial ratio analysis of krishak Bharati Cooprerative Limited. International Journal of Marketing, Financial Services \& Management Research. Vol 1 Issue 10

6. Durrah, O., Rahman, A. A. A., Jamil, S. A., \&
Ghafeer, N. A. (2016). Exploring the Relationship between Liquidity Ratios and Indicators of Financial Performance: An Analytical Study on Food Industrial Companies Listed in Amman Bursa. International Journal of Economics and Financial Issues, 6(2).

7. Marques, J. P. D. C. A. (2011). Return on Equity: A comparison between companies in Portugal and Brazil: Similarities and Differences (Doctoral dissertation, Universidade Nova de Lisboa).

8. Bansal, R. (2014). A Comparative Financial Study: Evidence from Selected Indian Retail Companies. Journal of Finance and Investment Analysis, 3(3), 13-35.

9. Haile, M. B. (2014). Financial statement analysis of dashen bank of Ethiopia.ZENITH International Journal of Business Economics \& Management Research, 4(6), 18-25.

10. Brigham, Eugene F. and Joel F. Houston. Fundamentals of Financial Management, Ninth Edition, Harcourt College Publishers, Fort Worth, 2001 